Sociedades Precapitalistas, vol. 7, nº 2, e027, junio 2018. ISSN 2250-5121 Universidad Nacional de La Plata.

Facultad de Humanidades y Ciencias de la Educación.

Centro de Estudios de Sociedades Precapitalistas (CESP)

\title{
Comentario a una reseña que irrita
}

Carlos Astarita

Universidad Nacional de La Plata-Universidad de Buenos Aires, Argentina

Cita sugerida: Astarita, c. (2018). Comentario a una reseña que irrita. Sociedades Precapitalistas, 7(2), e027. https:// doi.org/10.24215/22505121e027 


\title{
Comentario a una reseña que irrita
}

\author{
Carlos Astarita
}

Universidad Nacional de La Plata, Argentina

Universidad de Buenos Aires, Argentina

Luis García Moreno reseñó el libro de Eleonora Dell'Elicine, En el principio fue el Verbo. Políticas del signo y estrategias del poder eclesiástico en el reino visigodo de Toledo (589-711), editado por la Universidad de Cádiz en $2013^{1}$. Su comentario crítico llama a la crítica.

El Dr. García Moreno (GM) se alinea en una práctica que se hizo usual en la profesión: en la reseña se proclama lo que se siente por un colega, por una escuela o por una ideología. Los elogios y las rabietas son sus consecuencias, como muestra GM atacando a la Dra Dell'Elicine. De ella le molesta todo; incluso sus virtudes: el título es "bonito" aunque refleja "la habilidad «porteña» para jugar con la lengua española". Sin descartar que entre esos juguetones de la palabra haya tenido en la mente a Borges, GM relaciona esa "habilidad"con José Luis Romero, y lamenta que Dell'Elicine declare admirarlo relegando a Claudio Sánchez Albornoz. La insinuación es clara: Romero concibió una historia retóricamente efectiva (¿o efectista?) que atrajo a Dell'Elicine. La referencia no deja de mostrar una inequívoca animosidad dirigida al padre de la historia social argentina y a una producción historiográfica.

No es lo que GM expresaba en otros momentos. En 1995 participó junto a Tulio Halperin Donghi, José Emilio Burucúa, Roger Chartier, Ruggiero Romano, Domingo Plácido, José Ángel García de Cortázar, Felipe Maíllo Salgado, Reyna Pastor, José Luis Martín, Ángel Castellán y Hugo Zurutuza de un número homenaje a José Luis Romero de la revista de la Universidad de Buenos Aires Anales de Historia Antigua y Medieval № 28. Numerosos colegas tenían (y tienen) una elevada opinión de Romero. Como director de la revista lo invité a GM a participar en ese homenaje porque me había dicho (en conversación privada) que la lectura de La revolución burguesa en el mundo feudal le había abierto horizontes en la época del franquismo.

Ahora sabemos que ha cambiado de opinión, y ello no es condenable; establecer juicios con xenofobia sí lo es e irrita. El lo sabe, y por eso se apresuró a decir "que nadie piense que tengo algún prejuicio hacia la Universidad de la fraterna nación austral”. El descargo confirma sus sentimientos.

La crítica a Dell'Elicine se desliza por distintas cuestiones. Algunas se refieren a lo que un historiador valora en su análisis. Por ejemplo, GM se queja de que la autora del libro considere significativo que Isidoro determinara que los clérigos debían enseñar las Escrituras. No justifica el argumento; solo denuncia una elección.

También afirma que la lectura le recordó el Libro rojo del cole. Esta referencia a una condena del sistema educativo conservador pareciera ser, en un examen superficial, una extemporánea intromisión política en un comentario académico, pero lo que desconcierta por su forma logra su razón de ser en la totalidad discursiva. Coincide con la concepción tradicional y empirista de GM a quien le cedemos la palabra para que se defina expresivamente como "un castellano viejo, de los que llaman «al pan pan y al vino vino»". No sorprende entonces que se enoje ante las páginas que en el libro de Dell'Elicinese dedican "al «silencio» como instrumento ideológico del poder de la jerarquía eclesiástica". 
En este punto es oportuno revelar que no participo de los criterios metodológicos y teóricos de Dell'Elicine. Pero justamente el juicio personales lo que en una primera instancia debe dejarse de lado si se pretende comprender un trabajo. Obviamente tampoco interesan las opiniones de GM sobre este tema (y mucho menos interesan sus gustos o disgustos sobre las reseñas, como nos cuenta con un tono autorreferencial típico del comentarista convencido de que importa más que el autor que comenta). El problema es situarse en la lógica del autor, lo cual debería ser previo a cualquier consideración crítica, y la lógica de Dell'Elicine es la de un Althusser que valoriza y habla, por ejemplo, del silencio filosófico de Marx después de haber escrito las Tesis sobre Feuerbach. Los que adhieren a ese criterio se detienen por igual en lo que se dijo y en lo que no se dijo porque para ellos el mutismo expresa tanto como las palabras.

GM no analiza; más bien denuncia y se burla.Con tono mordaz descalifica, por ejemplo, la proposición de Dell'Elicine sobre la necesidad del receptor de un mensaje no verbal de interpretar lo que ve. Es una idea que manejaron otros estudiosos. Pierre Francastel, por ejemplo, habló de civilizaciones basadas en la vista y en el oído ${ }^{2}$. En absoluto es descabellado aplicar esta afirmación al Medioevo, y ningún medievalista ignora que Jacques Le Goff realizó un sugestivo análisis del lenguaje gestual ${ }^{3}$.

En ocasiones GM pasa de la observación general a la meticulosidad del erudito. Dice que no siempre las traducciones de Dell'Elicine son aceptables. Agrega: “Como ejemplo señalaré la importancia que la autora concede a la mención del término ordo para mostrar uno de los objetivos principales del proyecto isidoriano, sin darse cuenta [de] que el vocablo latino (máxime en el sintagma eclesiasticus ordo) nada tiene que ver con el sentido que tiene la expresión española «una sociedad ordenada»".

Un conocedor del Medioevo, posiblemente no inferior a GM, opinó distinto: "Gregorio I (492-496) incorpora como fundamento del conjunto de distinciones que definirán al clero, a partir de ese instante, los cimientos de una teoría política. Dos órdenes (uterque potestas, uterque ordo) regirán el mundo: uno de ellos, el de los clérigos, poseerá la autoridad (autorictas) y el otro, el de los soberanos, el poder (potestas)" ${ }^{4}$.

Otras elaboraciones han girado en torno a los famosos tres órdenes del idealizado ordenamiento social del feudalismo, y se habló en esa materia sociológica del cambio posterior de la palabra orden, de origen eclesiástico, por la palabra estado, lo que habría denotado una laicización de las estructuras mentales ${ }^{5}$.

El comentarista indica a continuación una serie de errores de información en los que ha incurrido la autora. Por ejemplo, que ha escrito mal el nombre de algún rey visigodo. Nada es objetable en este reproche excepto dos cuestiones. La primera es que con el enunciado de errores se dejó de lado la tesis del libro. El árbol impidió que se viera el bosque, y a veces (como en este caso) importa el conjunto. El segundo aspecto es que esas falencias de Dell'Elicine se reparten en 306 páginas. En el uno por ciento de ese espacio, o sea, en solo tres páginas, GM escribió mal el nombre de la autora que reseña en seis oportunidades.

Nuestro censor termina reconociendo que su escrito no es amable; no obstante alienta a esta "nueva estudiosa de la España goda” a que prosiga su trabajo desde "la lejana Buenos Aires” asimilando la bibliografía que leyó para proceder a "un análisis riguroso y aparentemente menos ambicioso, de las muchas fuentes que ha reunido y usado."

Es un párrafo sin desperdicios. Reúne eurocentrismo y petulancia para recomendar el ancestral positivismo. Entretanto no advirtió que la historiadora criticada pensó. Es lo que muchos no hacen y por eso no se arriesgan a una crítica como la que hizo el doctor García Moreno.

\section{Notas}

1 Hispania, LXXVI, 252, 2016, pp. 275-300. Esta revista se negó a publicar el presente comentario. La negativa confirma que su dirección avala opiniones queal descalificar a una colega desacreditan la cultura de un pueblo. No es de menor interés el pretexto: la revista no da cabida a debates sobre reseñas. Ello no siempre fue así:en esas páginas publiqué mi respuesta a reseñas de Adeline Rucquoi y Denis Menjot (C. Astarita "La insoportable levedad de la lectura", Hispania, LIX, 202, 1999, pp. 721-730). También alega que Hispania no es una revista de debate historiográfico, pero se le permite 
al señor Garcia Moreno que ejerza su grosera y chauvinista forma de debatir. Cabe agregar que cualquier persona con un mínimo de experiencia reconoce en qué casillero del espacio político se ubica estemanejo.

2 P. Francastel, “Arete y sociedad. Dimensión y medida de la civilizaciones”, en E. Balibar et al., Hacia una nueva historia, trad, cast. Madrid, 1976, pp. 65 y 80.

3 J. Le Goff, "Le rituel symbolique de la vassalité", en id., Pour un autre Moyen Age. Temps, travail et culture en Occident: 18 essais, París, 1977, pp. 349-420.

4 “Odene/órdenes", en J. Le Goff y J-C. Scmitt (ed.), Diccionario razonado de Occidente, trad. cast. Madrid, 2003 , p. 616.

5 G. Duby, Les trois ordres ou l'imaginaire du féodalisme, París, 1978. 